\title{
Evaluation of suppressor immune regulatory function in idiopathic congestive cardiomyopathy and rheumatic heart disease ${ }^{\star}$
}

\author{
JEFFREY L ANDERSON, † JAY H GREENWOOD, HIDENORI KAWANISHI \\ From the University of Michigan School of Medicine, Department of Internal Medicine, Ann Arbor, Michigan, USA
}

SUMMARY Several diseases with autoimmune features have recently been shown to be characterised by defects in suppressor cell immune regulation. Aberrant immune mechanisms of primary importance have been sought but not yet demonstrated for idiopathic congestive cardiomyopathy and rheumatic heart disease. We tested whether defective immunoregulatory function might explain certain features of these diseases. Peripheral blood mononuclear cells from patients with both diseases showed normal proliferative responses in the mixed leucocyte reaction. Concanavalin $\mathrm{A}$ induced similar suppressor activity, quantified in mixed leucocyte reaction as a suppression index, among control subjects, patients with rheumatic heart disease, and patients with idiopathic congestive cardiomyopathy. Similarly, patient serum supported induction of suppressor activity in normal leucocytes equal to that of control serum. A chronic immunoregulatory defect thus does not appear necessary for the development of idiopathic congestive cardiomyopathy or rheumatic heart disease.

The involvement of immunological reactions in several aspects of cardiac disease has become increasingly evident in recent years. ${ }^{12}$ Antiheart antibodies have been described in the postpericardiotomy and related syndromes, ${ }^{2}$ in infectious endocarditis, ${ }^{3}$ and in rheumatic fever and primary myocardial disease. ${ }^{245}$ Rejection of cardiac allografts in transplant patients is associated with activation of both humoral and cellular immune processes. ${ }^{26}$ The development of lymphomas in a significant percentage of immunosuppressed cardiomyopathy patients after cardiac transplantation also suggests the operation of aberrant immune mechanisms.

Immune dysfunction of primary importance has been postulated but not fully demonstrated in idiopathic congestive (dilated) cardiomyopathy and rheumatic heart disease. Cross reactivity between streptococcal antigens and myocardial membrane antigens has been described in rheumatic fever. ${ }^{2}$ This abnormal reactivity persists for at least several years. $^{28}$ Streptococcal-induced, cell-mediated im-

\footnotetext{
* This project supported by grants from the Michigan Heart Association and The Biomedical Research Council, University of Michigan.

† Present address: University of Utah School of Medicine, Cardiovascular Division, Salt Lake City, Utah, 84132 USA.

Received for publication 10 March 1981
}

mune destruction of cardiac myofibres has also been shown in vitro. ${ }^{9}$ An autoimmune process initiated by a previous viral infection has been suggested as an aetiology of congestive cardiomyopathy but requires further verification. ${ }^{10-13}$ Other workers have suggested that humoral and cell-mediated immune abnormalities may represent secondary rather than primary aetiological processes. ${ }^{14} 15$

Recent attention has been directed to the importance of suppressor-lymphocyte function in the normal regulation of both cellular and humoral immune responses and of disorders of suppressor cell function in many animal and human diseases with autoimmune features. ${ }^{16-21}$ Of further interest is the finding in some patients of serum factors which block the induction of suppressor activity in normal lymphocyte populations. ${ }^{22} 23$

Immunoregulatory dysfunction in cardiac disease was recently suggested in a study by Fowles et al. ${ }^{24}$ Defective in vitro suppressor cell function was reported in idiopathic congestive cardiomyopathy but not in coronary artery disease. To evaluate further the possibility of immunoregulatory deficiency in cardiac disease, we undertook a study in patients with idiopathic congestive cardiomyopathy and rheumatic heart disease. We examined the ability of peripheral 
blood mononuclear cells and serum from these patients to support the induction of suppressor activity in vitro.

\section{Patients and methods}

Four groups of patients were studied. The first group included nine healthy subjects: seven women and two men, aged 20 to 56 years (mean 34.3 years). The second group included nine patients with chronic rheumatic heart disease: seven women and two men, aged 39 to 67 years (mean 52.9 years). Functional class (New York Heart Association) was 2 or 3. The third group comprised eight patients with idiopathic congestive cardiomyopathy: two women and six men, ages 15 to 70 years (mean 42.9 years). Functional class averaged $3 \cdot 3$, range 2 to 4 . Known causes of heart failure were excluded. The duration of heart failure was greater than one year in four and less than one year in the other four. Endomyocardial biopsy, ${ }^{25}$ performed in three, disclosed changes consistent with cardiomyopathy without myocarditis. The fourth group consisted of seven patients with other chronic diseases: alcoholic cardiomyopathy (two), inactive rheumatic diseases (three), chronic pulmonary disease (one), and inactive neurological disease (one). Group 4 included four women and three men, ages 20 to 59 years (mean 43.9 years).

\section{CELL CULTURE TECHNIQUES}

Peripheral blood mononuclear cells were separated from heparinised blood by Ficoll-Hypaque density gradient centrifugation according to a standard technique. ${ }^{26} 27$ These predominantly lymphocyte preparations were found to include approximately $7 \%$ esterase positive (macrophage) cells.

Suppressor activity was induced by the addition of concanavalin A (con A) at a final concentration of 20 $\mu \mathrm{g} / \mathrm{ml}$ to peripheral blood mononuclear suspensions followed by incubation for either 24 or 48 hours at $37^{\circ} \mathrm{C}$ in $5 \%$ humidified $\mathrm{CO}_{2} .^{28}{ }^{29}$ At the end of incubation, suppressor cells were irradiated to prevent replication (cobalt-60, $2000 \mathrm{rads} / 8 \mathrm{~min}$ ). Parallel cultures without con A served as controls. "Suppressed" and "simple" mixed leucocyte reactions consisted of six day microwell cultures $(0.2 \mathrm{ml})$ containing equal numbers $\left(10^{5}\right)$ of responder cells, irradiated allogeneic stimulator cells, and either the responder's con A-activated effector (suppressor) cells or his non-activated (control) cells, respectively. ${ }^{24} 28$

During the last 24 hours of incubation, $1 \mu \mathrm{Ci} /$ well of tritiated thymidine was added; cellular uptake of thymidine was measured by liquid scintillation by averaging four replicate wells. The suppression index representing the percentage inhibition of responder cell blastogenesis by con A-activated effector cells, was equal to $\left[1-\left(n_{4}-n_{3}\right) /\left(n_{2}-n_{1}\right)\right] \times 100$, where $n_{4}, n_{3}$ represent $\mathrm{cpm}$ of responder cells in the presence of autologous con A-activated cells with $\left(n_{4}\right)$ or without $\left(n_{3}\right)$ allogeneic stimulator cells, and $n_{2}, n_{1}$ represent $\mathrm{cpm}$ of responder cells in the presence of autologous non-activated cells with $\left(n_{2}\right)$ or without $\left(n_{1}\right)$ allogeneic stimulator cells.

To test for the presence of leucocyte (lymphocyte) conditioning factors $\mathrm{s}^{22}$ in patient serum, suppressor activity was induced by con $A$ treatment of peripheral blood mononuclear suspensions from normal subjects in the presence of $10 \%$ patient serum, then assayed in mixed leucocyte reaction as above.

Control experiments included: (1) cultures containing responder cells alone and in the presence of either activated or non-activated effector cells; (2) variations in time of mixed leucocyte reaction incubation (four to seven days); (3) two to four fold variations in numbers and ratios of individual cell types in mixed leucocyte reactions $\left(2 \times 10^{4}\right.$ to $2 \times 10^{5}$ cells/well); and (4) tests of the effects of serum from differing sources on results of simple and con A-activated mixed leucocyte reaction. Sera tested included separate batches of pooled human serum (Flow Laboratories, Rockville, MD), pooled human AB serum (Gibco, Grand Island, $\mathrm{NY}^{24}$ ), horse serum (Gibco), and sera from several individual subjects and patients. (5) In order to document the dependence of suppressor activity on a radiation-sensitive cell population, ${ }^{30}$ aliquots of peripheral blood mononuclear cells were subjected to $750 \mathrm{rads}(48 \mathrm{rads} / \mathrm{min})$ of cobalt-60 irradiation before con A-activation. Control aliquots were shielded by a lead container. Chenodeoxycholic acid (CDCA, $100 \mu \mathrm{g} / \mathrm{ml}$ ), which also leads to specific loss of suppressor lymphocytes, was used together with con A to treat peripheral blood mononuclear cells during the 48 hour effector cell induction period in other experiments. ${ }^{31}$

\section{Results}

RESULTS OF SIMPLE AND SUPPRESSED MIXED LEUCOCYTE REACTIONS

Responder peripheral blood mononuclear leucocytes from control subjects and patients in both cardiac groups showed brisk proliferation reactions in the simple mononuclear leucocyte reactions (Fig.). Substantial suppressor activity was also induced in peripheral blood mononuclear suspensions from control subjects and patients with rheumatic heart disease and congestive cardiomyopathy by addition of con A-activated autologous cells to the mononuclear leucocyte. reactions ( $p<0.001$, control vs activated, -Fig.) Net differences among the groups in either control or activated mononuclear leucocyte reaction responses were not significant $(p>0.05)$. Suppression 


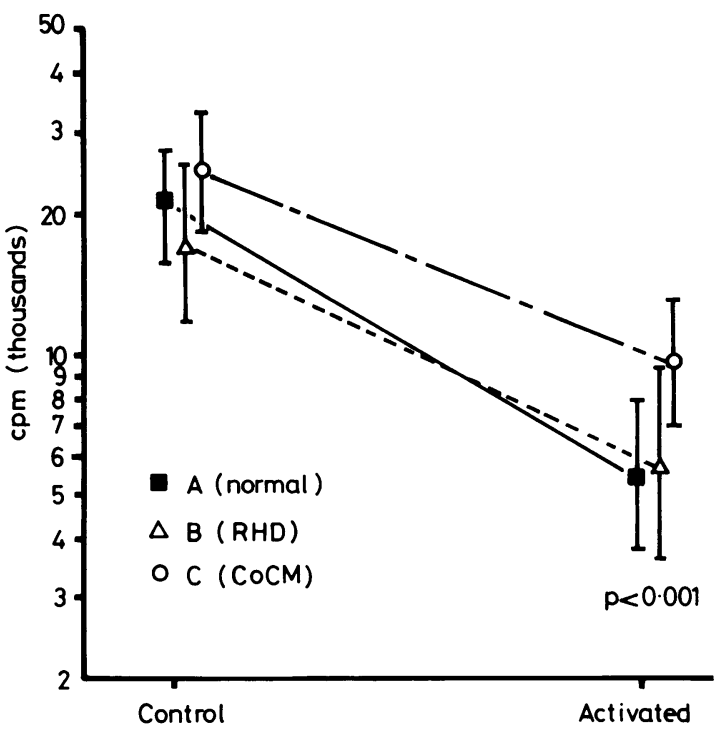

Fig. Results of simple (control) and suppressed (activated) mononuclear leucocyte reactions. I sotope incorporation of tritiated thymidine (cpm) given for responder cells in the presence of allogeneic stimulator cells in the absence (control) or presence (activated) of con A-activated peripheral blood mononuclear suppressions. Counts per minute (cpm) in thousands are displayed on a logarithmic scale on the ordinate for three subject groups: normal $(A)$, rheumatic heart disease $(B)$, and idiopathic congestive cardiomyopathy $(C)$. Data were plotted as geometric means ( $\pm S E M) . P$ values result from group comparisons of individual control vs activated studies.

index averaged $68 \cdot 7 \pm 6 \cdot 1 \%$ SEM $(n=9)$, range 41 to $95 \%$, in normal subjects; $62 \cdot 7 \pm 8 \cdot 1 \%(n=9)$, range 9 to $84 \%$, in patients with rheumatic heart disease; $57 \cdot 4 \pm 7 \cdot 6 \%(n=8)$, range 20 to $85 \%$, in congestive cardiomyopathy patients; and $79 \cdot 1 \pm 5 \cdot 1 \%(\mathrm{n}=7)$, range 56 to $96 \%$, in those with miscellaneous diseases. There were no significant differences in suppression index comparing each group with control group 1, all groups simultaneously, or combined groups 1 plus 4 (controls) with 2 plus 3.

SERUM EFFECTS ON SUPPRESSOR ACTIVITY Incubation ("conditioning") of peripheral blood mononuclear suspensions from normal subjects with sera from various patients failed to depress con A-induction of suppressor activity. Sera from each of nine patients with rheumatic heart disease supported generation of suppressor activity during con Aincubation with normal peripheral blood mononuclear suspensions as demonstrated by a mean suppression index of $59 \cdot 3 \pm 7 \cdot 6 \%$, range 26 to $94 \%$. Similarly, incubation with serum from patients with congestive cardiomyopathy resulted in a mean suppression index of $69 \cdot 2 \pm 8 \cdot 2 \%(n=6)$, range 41 to
93\%. Conditioning with serum from patients with other chronic diseases resulted in a mean suppression index of $70 \cdot 7 \pm 9.8 \%(n=7)$, range 69 to $100 \%$. As noted above, suppression index for cells from normal subjects incubated with a single source of pooled human serum (Flow) was $68 \cdot 7 \pm 6 \cdot 1 \%(n=7)$, range 41 to $95 \%$. No statistically significant differences resulted when cardiac groups 2 or 3 were compared with either of the two control groups, when all groups were compared simultaneously, or when combined control vs cardiac groups were compared.

Source of commercial serum was a significant variable. Two batches of pooled human serum from one source (Flow) supported excellent responses of normal peripheral blood mononuclear suspensions in both simple mononuclear leucocyte reactions (43, 48 fold average cpm increase) and in suppressed mononuclear leucocyte reaction (mean suppression index $=57 \%, 53 \%$ ). In contrast, pooled human $\mathrm{AB}$ serum obtained from a source used in other work ${ }^{24}$ yielded a flat response; no stimulation occurred in mononuclear leucocyte reaction and no suppression in con A-activated mononuclear leucocyte reactions. Blunted responses occurred in the presence of horse serum in both mononuclear leucocyte reactions (seven fold increase in cpm) and suppressed mononuclear leucocyte reactions (mean suppression index 11\%).

RESPONSE OF SUPPRESSOR REACTION TO ASSAY VARIATIONS

Results on day 6 provided optimal contrasts between simple and suppressed mononuclear leucocyte reactions in both control and patient groups though contrasts were also present on days 4 to 7 . Induced suppressor activity was largely independent of con A-concentration over the range tested (5 to 60 $\mu \mathrm{g} / \mathrm{ml}) .{ }^{29}$ The $20 \mu \mathrm{g} / \mathrm{ml}$ concentration avoided the occasional toxicity and greater background cpm of the highest concentration and suboptimal induction of the lowest concentration. Variations in cell numbers and ratios did not cause substantial differences in simple or con A-activated mononuclear leucocyte reactions. Cell numbers of $5 \times 10^{4}$ or $1 \times 10^{5}$ per well of each cell type at equal or twofold differing cell ratios (enriched for effector cells) gave excellent results.

RESPONSE AFTER ELIMINATION OF SUPPRESSOR CELLS

Treatment of peripheral blood mononuclear suspensions with either low dose irradiation ${ }^{30}$ before con A-induction or with bile $\mathrm{acid}^{31}$ during con $A$-induction prevented the generation of suppressor activity by con $A$ (Table). In subjects $A$ and $B$, con $A$ induced suppressor activity in sham-irradiated cells (suppression index 100\%, 95\%); in contrast, obvious stimulation rather than suppression followed addition 
Table Effect of elimination of suppressor cells on con A-activated mixed leucocyte reaction

\begin{tabular}{clc}
\hline Subject & Treatment & $\%$ Suppression \\
\hline I: (A) & (1) Control, suppressed mononuclear & \\
& leucocyte reaction & 95 \\
& (2) 750 Rads, before con A induction & -100 \\
(B) & (1) Control, suppressed mononuclear & \\
& leucocyte reaction & 100 \\
& (2) 750 Rads, before con A induction & -133 \\
\hline
\end{tabular}

II: (C) (1) Control, suppressed mononuclear leucocyte reaction 77

(2) Chenodeoxycholic acid during induction $(n=3)$ $-26$

Effects of selective elimination of suppressor cells from normal subjects on con A-activated mononuclear leucocyte reactions: In I, irradiation pretreatment is used to inactivate potential suppressor cells. In II, suppressor cell induction is blocked by chenodeoxycholic acid.

of preirradiated con A-treated effector cells to mononuclear leucocyte reactions (suppression index $-333 \%,-100 \%)$. In subject $\mathrm{C}$, con $\mathrm{A}$ induced suppressor activity in untreated peripheral blood mononuclear suspensions (suppression index $77 \%$ ), but stimulation rather than suppression followed incubation with CDCA during con A-induction $(n=3$, mean suppression index $-26.0 \%$ ). Thus, elimination of suppressor activity resulted from pretreatments known to interrupt suppressor lymphocyte function, and unmasking of latent helper lymphocyte function was suggested by a subsequent increase in thymidine incorporation.

\section{Discussion}

We found normal immunoregulatory function, as assessed by inducible in vitro suppressor activity, in patients with idiopathic congestive cardiomyopathy and rheumatic heart disease. Of the common cardiac diseases, these have been most often mentioned as potentially involving immune mechanisms. ${ }^{2}$ \&-13 Persistent reactivity to antigenic stimuli caused by defective immunoregulation might be postulated in these diseases. Our data, however, do not support an essential role for chronic immunoregulatory dysfunction. Other immune abnormalities and subtle or transient immunoregulatory defects cannot be excluded.

The ability to induce normal suppressor activity suggests that a suppressor cell population, presumably consisting of suppressor $(T-\gamma)$ lymphocytes and perhaps also monocytes, is present in these diseases. ${ }^{16} 17$ Patient serum was also found to be devoid of factors inhibiting induction of suppressor activity. Dependence of suppression on a subpopulation of effector cells was confirmed by abolition of suppression by low-dose irradiation and bile acids, methods known selectively to eliminate suppressor $\mathrm{T}$ cells. $^{30} 31$ These experiments confirm that the assay can determine if a patient's suppressor-precursor population is either absent or functionally inhibited (as by serum factors) during the con A-induction period.

The finding of normal inducible suppressor activity in congestive cardiomyopathy contrasts with a recent report by Fowles et al. ${ }^{24}$ In that report, peripheral blood mononuclear suspensions from healthy subjects and patients with coronary artery disease but not congestive cardiomyopathy caused suppression of mononuclear leucocyte reactions. No patient with congestive cardiomyopathy in their series displayed a suppression index greater than $22 \%$ (mean suppression index $-66 \%$ ). In contrast, the suppression index in every patient with congestive cardiomyopathy in our series was greater than $20 \%$. The reasons for this discrepancy are not clear. Review of clinical features fails to differentiate the two series. Some but not other aetiological agents (that is cardiotropic viruses) might then be invoked. The fact that the Stanford series included cardiac transplant candidates referred from various parts of the USA argues somewhat against a geographical explanation. Temporal variation in aetiological agents associated with the postpericardiotomy syndrome has recently been reported. ${ }^{32}$ In this regard, however, immunoregulatory abnormalities associated with systemic lupus erythematosus appear to be genetic rather than acquired. ${ }^{33}$

Our assay methodology closely resembles that of others. ${ }^{24}$ 26-28 Small overall (but not intergroup) differences may have resulted from the use of responder cells alone as controls in the Stanford study $^{24}$ rather than responder and effector cells together. Technician bias in our results was avoided by blinding those analysing the in vitro assays to the patient-source of blood samples. Differences in serum factors may be of relevance. We found that certain batches of commercially available sera of both human and animal origin did not support ideal normal or suppressed mononuclear leucocyte reaction responses. That freshly drawn human serum usually supports a vigorous mononuclear leucocyte reaction and suppressed mononuclear leucocyte reaction response, however, was shown by results of incubations with serum from each of 22 subjects. If the commercial serum used by the Stanford group provided more stringent conditions for the induction of suppressor activity than serum used in our study, subtle differences in response-potential between patient and control cells, not detected by our assay, may have been elicited.

The recent availability of antisera directed against specific T-lymphocyte populations should allow direct 
determinations of suppressor and helper cell numbers in congestive cardiomyopathy and rheumatic heart disease and may add further information to the assessment of the immunoregulatory system in these diseases. ${ }^{17} 21$

We thank Dr Sunil Das, Dr Stanley Schwartz, and Dr Bertram Pitt for helpful suggestions.

\section{References}

1 Lessof $\mathrm{M}$. Immunological reactions in heart disease. $\mathrm{Br}$ Heart $\mathcal{f}$ 1978; 40: 211-4.

2 Zabriskie J, Engle $M$, Villarreal $\mathrm{H}$, eds. Clinical immunology of the heart. New York: Wylie, 1981.

3 Das SK, Cassidy JT. Importance of heart antibody in infective endocarditis. Arch Intern Med 1977; 137: 591-3.

4 Das SK, Callen JP, Dodson VN, Cassidy JT. Immunoglobulin binding in cardiomyopathic hearts. Circulation 1971; 44: 612-6.

5 Bolte HD, Grothe K. Cardiomyopathies related to immunological processes. In: Riecker G, Weber A, Goodwin J, eds. Myocardial failure. Berlin: SpringerVerlag, 1977; 266-74.

6 Anderson JL, Fowles RE, Stinson EB, Yuge C, Bieber $\mathrm{CP}$, Harrison DC. Occurrence of circulating heartreactive antibodies in a population of cardiac transplant recipients. Circulation 1979; 60: 629-37.

7 Anderson JL, Fowles RE, Bieber CP, Stinson EB. Idiopathic cardiomyopathy, age, and suppressor-cell dysfunction as risk determinants of lymphoma after cardiac transplantation. Lancet 1978; ii: 1174-7.

8 Read SE, Fischetti VA, Utermohlen V, Falk RE, Zabriskie JB. Cellular reactivity studies to streptococcal antigens. $\mathcal{F}$ Clin Invest 1974; 54: 439-50.

9 Yang LC, Soprey PR, Wittner MK, Fox EN. Streptococcal-induced cell-mediated-immune destruction of cardiac myofibers in vitro. $\mathcal{F}$ Exp Med 1977; 146: 344-60.

10 Kawai C, Takatsu T. Clinical and experimental studies on cardiomyopathy. $N$ Engl F Med 1975; 293: 592-7.

11 Cambridge G, MacArthur CGC, Waterson AP, Goodwin JF, Oakley CM. Antibodies to Coxsackie B viruses in congestive cardiomyopathy. Br Heart f 1979; 41: 692-6.

12 Anonymous. Virus, immunology and the heart (editorial). Lancet 1979; ii: 1111-3.

13 Wong CY, Woodruff JJ, Woodruff JF. Generation of cytotoxic T-lymphocytes during Coxsackievirus $B_{3}$ infection. II. Characterization of effector cells and demonstration of cytotoxicity against viral-infected myofibers. F Immunol 1977; 118: 1165-9.

14 Kirsner AB, Hess EV, Fowler NO. Immunologic findings in idiopathic cardiomyopathy: a prospective serial study. Am Heart $\mathcal{f}$ 1973; 86: 625-30.

15 Jacobs B, Matsuda Y, Deodhar S, Shirey E. Cellmediated cytotoxicity to cardiac cells of lymphocytes from patients with primary myocardial disease. Am $\mathcal{F}$ Clin Pathol 1979; 72: 1-4.

16 Waldmann TA, Blaese RM, Broder S, Krakauer RS. Disorders of suppressor immunoregulatory cells in the pathogenesis of immunodeficiency and autoimmunity. Ann Intern Med 1978; 88: 226-38.
17 Reinherz EL, Schlossman SF. Regulation of the immune response-inducer and suppressor T-lymphocyte subsets in human beings. $N$ Eng $\mathcal{F}$ Med 1980; 303: 370-3.

18 Decker JL, Steinberg AD, Reinertsen JL, Plotz PH, Balow JE, Klippel JH. Systemic lupus erythematosis: evolving concepts. Ann Intern Med 1979; 91: 587-604.

19 Reinherz EL, Rubinstein A, Geha RS, Strelkauskas AJ, Rosen FS, Schlossman SF. Abnormalities of immunoregulatory T-cells in disorders of immune function. $N$ Engl f Med 1979; 301: 1018-22.

20 Hodgson HJF, Wands JR, Isselbacher KJ. Alteration in suppressor cell activity in chronic active hepatitis. Proc Natl Acad Sci USA 1978; 75: 1549-53.

21 Reinherz EL, Weiner HL, Hauser SL, Cohen JA, Distaso JA, Schlossman SF. Loss of suppressor T cells in active multiple schlerosis. $N$ Engl $\mathcal{f}$ Med 1980; 303: 125-9.

22 Twomey JJ, Laughter AH, Steinberg AD. A serum inhibitor of immune regulation in patients with systemic lupus erythematosus. $\mathcal{F}$ Clin Invest 1978; 62: 713-5.

23 Shore A, Limatibul S, Dosch HM, Gelfand EW. Identification of two serum components regulating the expression of $\mathrm{T}$-lymphocyte function in childhood myasthenia gravis. $N$ Engl f Med 1979; 301: 625-9.

24 Fowles RE, Bieber CP, Stinson EB. Defective in vitro suppressor cell function in idiopathic congestive cardiomyopathy. Circulation 1979; 59: 483-91.

25 Mason JW, Billingham ME, Ricci DR. Treatment of acute inflammatory myocarditis assisted by endomyocardial biopsy. Am f Cardiol 1980; 45: 1037-44.

26 Böyum A. Separation of leukocytes from blood and bone marrow. Scand 7 Clin Lab Invest 1968; 21, suppl 97: 51.

27 Thorsby E, Bois R, Bondevik H, et al. Joint report from a mixed lymphocyte culture workshop. Tissue Antigens 1974; 4: 507-25.

28 Shou L, Schwartz SA, Good RA. Suppressor cell activity after concanavalin-A treatment of lymphocytes from normal donors. I Exp Med 1976; 143: 1100-10.

29 Gupta S, Schwartz S, Good RA. Subpopulations of human T-lymphocytes. VII. Cellular basis of concanavalin A-induced T cell-mediated suppression of immunoglobulin production by B lymphocytes from normal humans. Cell Immunol 1979; 44: 242-51.

30 Kishimoto S, Tomino S, Mitsuya H, Fujiwara H. Age-related changes in suppressor functions of human cells. F Immunol 1979; 123: 1586-93.

31 Kawanishi H, Greenwood JH, Blackwell WH. Bile acids inhibiting lymphocyte proliferation and suppressor Tcell activity in cholestatic liver diseases (abstract). Gastroenterology 1980; 78: 1309.

32 Engle MA, Zabriskie JB, Senterfit LB, Gay WA, Jr, O'Loughlin JE, Ehlers KH. Viral illness and the postpericardiotomy syndrome. Circulation 1980; 62: $1151-8$.

33 Miller KB, Schwartz RS. Familial abnormalities of suppressor-cell function in systemic lupus erythematosis. N Engl f Med 1979; 301: 803-9.

Requests for reprints to Dr Jeffrey L Anderson, Cardiovascular Division, University of Utah Medical School, c/o LDS Hospital, 325 Eighth Avenue, Salt Lake City, Utah 84143, USA. 